\title{
SELF-IMAGE DEVELOPMENT AND IMAGES OF KALIBARU CILINCING AREA AS ONE OF NORTH JAKARTA TOUR DESTINATION THROUGH INSTAGRAM SOCIAL MEDIA
}

\author{
Elly Yuliawati, Rangga Kusuma Nagara, Bimo Azhary, \\ Muhammad Bagus Bintoro \\ Universitas Mercu Buana Jakarta, Indonesia
}

\begin{abstract}
The development of social media such as Facebook, Instagram, Twitter is no longer a stranger to the ears of Indonesian people, especially in Jakarta, including citizens who live in the Kalibaru area, Cilincing, North Jakarta. Even though the area is considered to be a slum and underdeveloped area, the fact is that almost all residents there have known and tried to follow the development of communication technology and social media. However, education especially for teenagers about using good and wise social media still needs to be improved.

This Community Service Program aims to equip young people in the Kalibaru area, Cilincing, North Jakarta how to use good social media to improve their self-image and the image of the region through social media Instagram. Changing people's views about the slums of the Kalibaru area into a beautiful area as a tourist attraction. The training method (workshop) applies an interactive discussion technique that involves all participants to actively participate in the activity.

The training results illustrate that teenagers in the Kalibaru area understand about the meaning of selfimage and the image of the region and also understand about the hope for self-image and the image of the Kalibaru area going forward. They gained new knowledge about the use of Instagram, the importance of caption, hash tag, the use of good and interesting grammar and mastery of photography techniques to build memorable information so that they can develop their self-image and the Kalibaru area as one of the tourist destinations in North Jakarta.
\end{abstract}

Keywords: Self-Image, Regional Image, Travel Destinations, Social Media, Instagram

\section{INTRODUCTION}

Jakarta as a center of economic activity also functions as the national capital and administrative center of the Republic of Indonesia, a center for social and cultural activities as well as a center for national defense and security activities. Jakarta's city development has the task of aligning Jakarta with other cities in the world. Being part of DKI Jakarta is not a definite measure for the surrounding area to be developed in terms of the economy, facilities and infrastructure; one example is the Kalibaru area, Cilincing. The Kalibaru area, Cilincing is located east of the Port of Tanjung Priok. The Kalibaru area, Cilincing is included in the North Jakarta Municipality.

Cilincing is one of several areas in DKI Jakarta that is still said to be a disadvantaged area, judging by the economic conditions of local residents and facilities and infrastructure that do not yet support it to be said to be livable, image of the Kalibaru, Cilincing Area that existed in DKI Jakarta residents for the first time hearing the word Cilincing is a slum, arid and remote area compared to the image of DKI Jakarta which has been known as a metropolitan city that is bustling with all its busy activities, especially with current technological advances that make it easier for everyone to get information about anything regardless information that is in accordance with the facts or not.

Kalibaru area, Cilincing today has changed a lot in terms of facilities and infrastructure, but the image that still exists in the community, seeing the Kalibaru, Cilincing area is still the same as the previous image, there needs to be a movement to show the new face of Cilincing so that gradually the negative image the attachment was replaced by a positive image, and it was hoped that Cilincing would become an area that was not left behind. One way that can be used is to show the other side of Cilincing through social media which is currently widely used by Indonesian people, especially among adolescents at the junior and senior high school levels. Some research shows problems in the use of social media by adolescents, which arise due to adolescents' lack of wisdom in using social media, especially personal problems that should not be disseminated which will have an impact on their self-image in the community or their peers.

Teenagers are agents of change that require supervision from parents and the surrounding environment, because this period is the most important period for shaping adolescents' mental systems and thinking. The role of parents in escorting adolescents is central, including providing supervision to adolescents to use media wisely so as to form a good image for themselves. 
The image formed through social media shows that many areas that were not so exposed by many people because of their ordinary image, but with the help of social media can form new images that are more attractive so that people's attention can be focused on these areas and their effects the most beneficial is being able to impact on the economy of the surrounding residents, here the task of teenagers is very large to contribute to shaping their self-image and Cilincing image even better. Therefore training and knowledge development are needed on how to use social media wisely and have a positive effect on him and the Kalibaru Area, Cilincing.

\section{PROBLEM}

Identification of the problems that occur in the Kalibaru Region youth, Cilincing namely the lack of training in the Kalibaru Region youth, Cilincing on how to use good and wise social media to form a good selfimage and Kalibaru, Cilincing Region.

\section{METHODS}

This service activity uses the training method with interactive discussion techniques that involve all participants. The workshop method is used in delivering material about imagery, the use of captions and hash tags, and photography techniques. To deepen the understanding of the training material, participants are given the opportunity to discuss, ask questions and do simulations. In addition, participants were also taught simple public relations competencies, which would later be beneficial for North Jakarta Kalibaru youth.

\section{RESULTS AND DISCUSSION}

Community Service Activities were carried out for 3 weeks with 3 meetings on November 25, December 2 and December 9, 2018 and held mentoring for approximately 12 days. Which is located at Rumah Kerang, Kalibaru, Cilincing, North Jakarta. There are several results that have been obtained in this activity in shaping self-image and the image of the Kalibaru area, Cilincing.

a. Writing Captions concept

Participants were given information on the importance of writing captions in social media to support the formation of self-image. The results of activities and monitoring carried out. Participants who previously often emptied or only provided certain symbols in the column Captions on Instagram, with this activity participants now began to dare to write captions that are more conceptualized to form their self-image.

solidinos

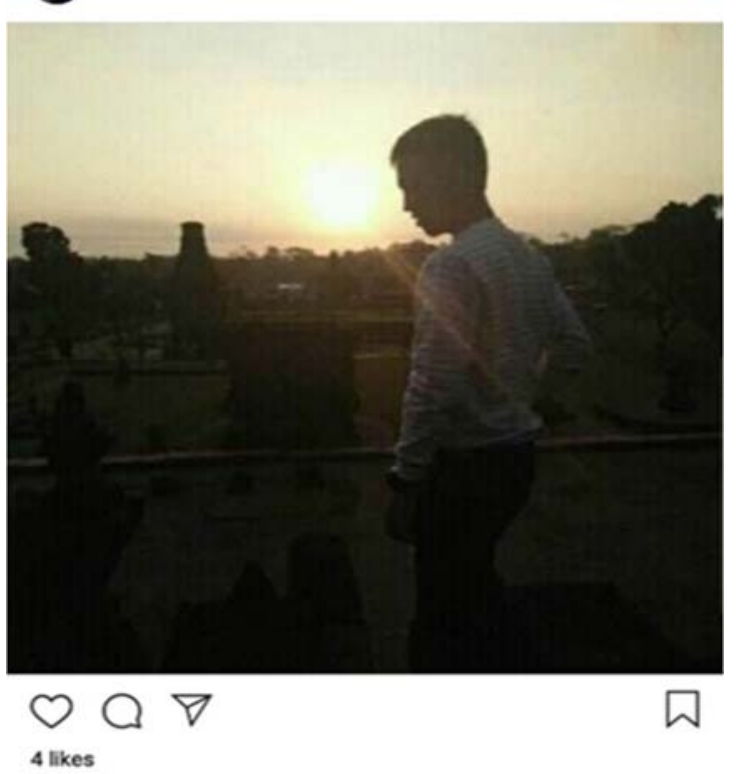

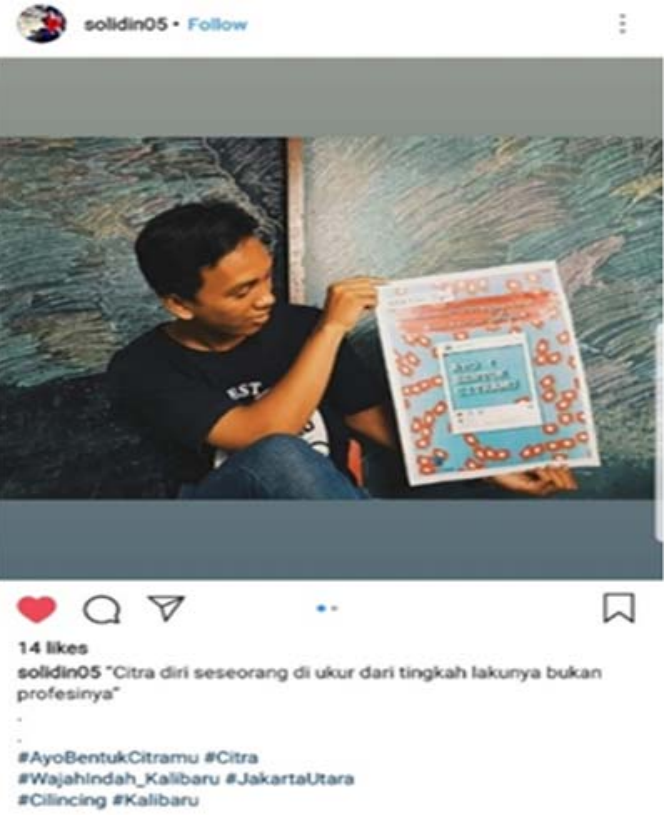




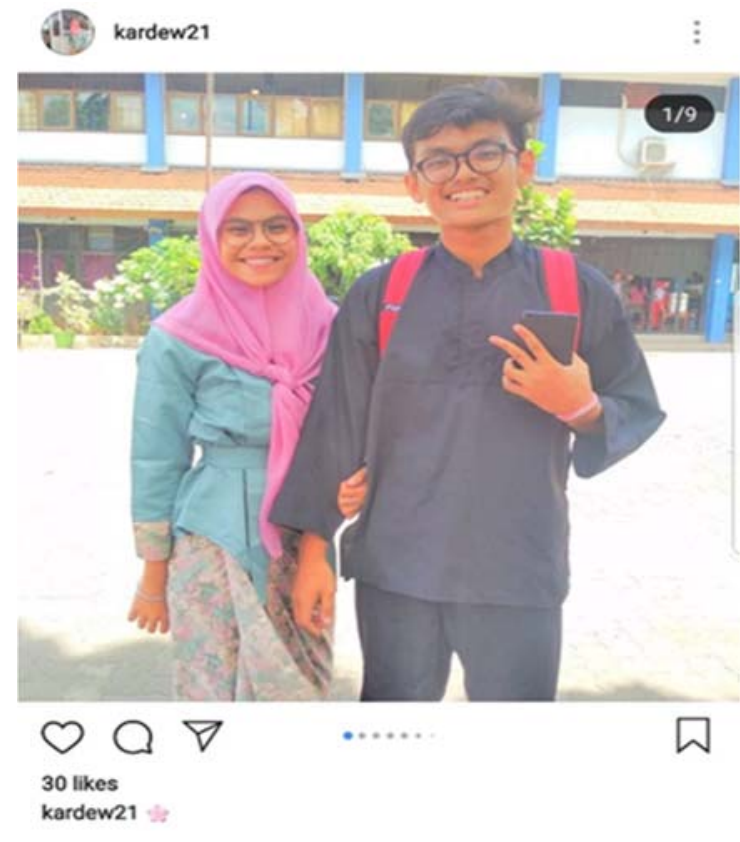

Figure 1. Instagram participants (Solidin) who took part in this activity, previously left the captions column blank.

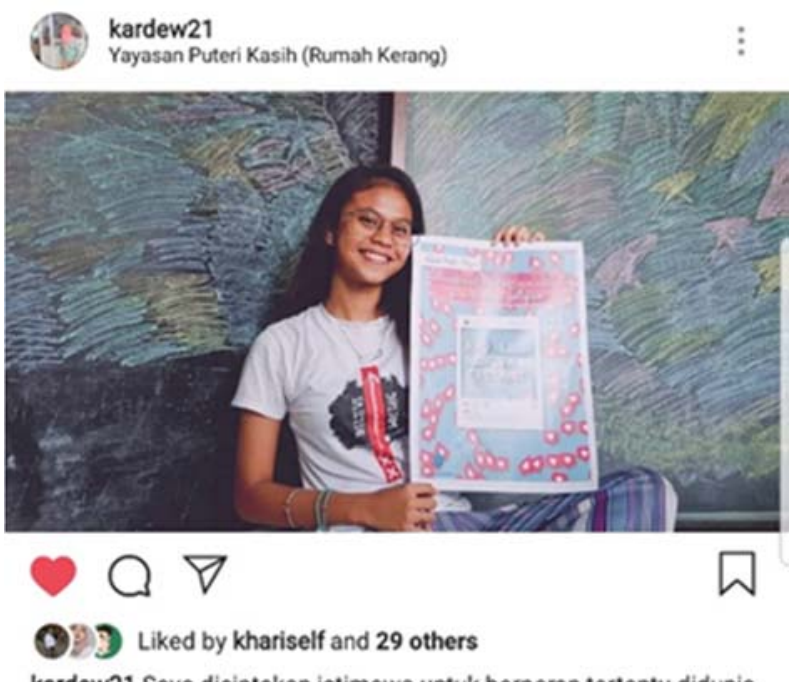

kardew21 Saya diciptakan istimewa untuk berperan tertentu didunia ini, dengan cara dan gaya saya, sehingga saya sukses dan bahagia 0

\#AyoBentukCitramu \#Citra \#WajahIndah_Kalibaru \#JakartaUtara \#Cilincing \#Kalibaru

Figure 2. Instagram participants after participating in PPM activities, in their Instagram column, they have added caption as an effort to form self-image

b. Knowing the Self-Image and the Image of the Region

Before the activity was held, participants did not understand what Citra meant. The first thing they think of when they hear the word "Citra" is brand soap, an artist's name, and so on. But after this activity was held, the participants understood what was meant by "image" as a picture or representation of an object. At present, participants already know what kind of self-image they want and how the region's current image and hope for the future.

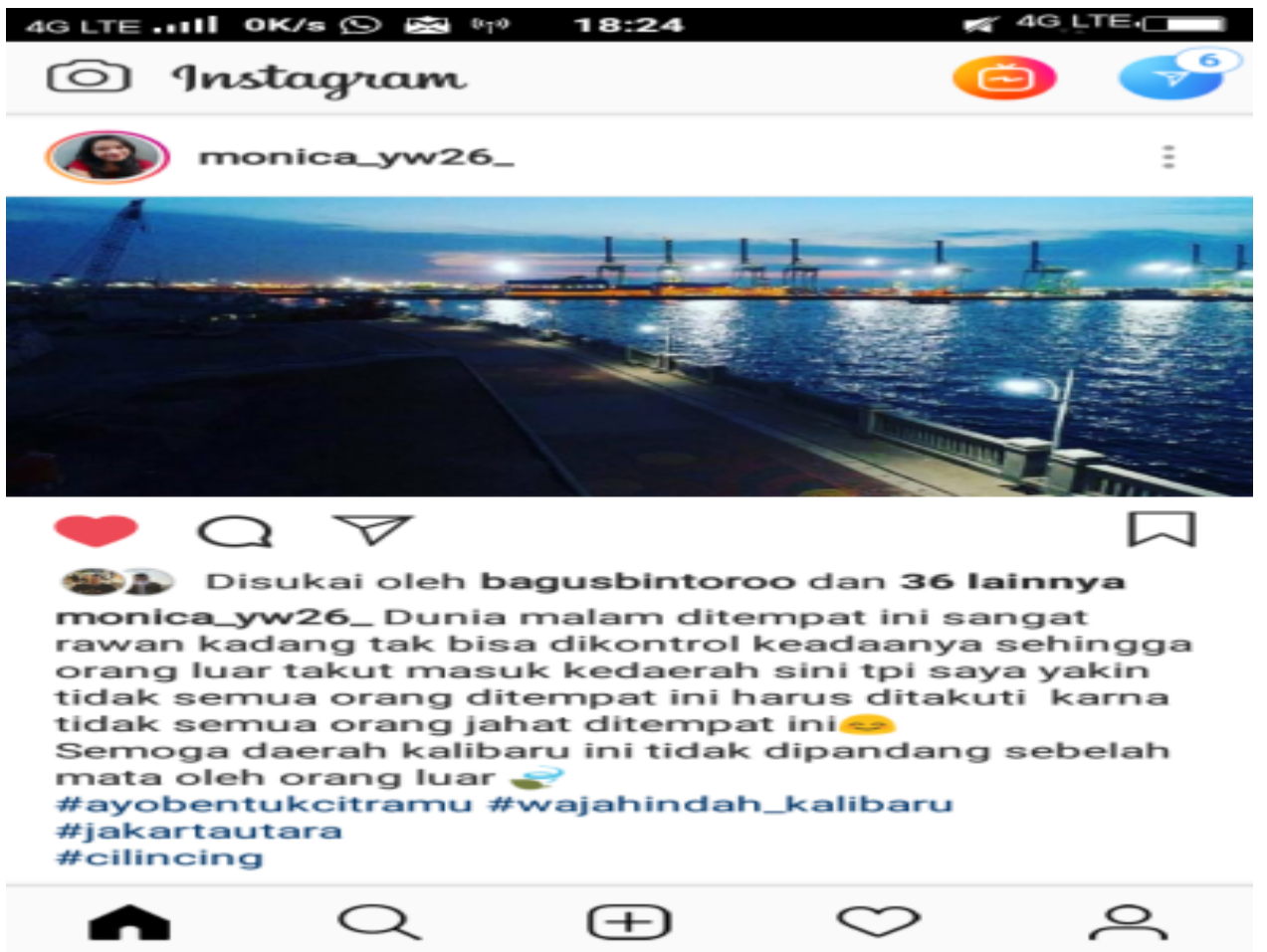

Figure 3. Participants can take advantage of Instagram social media especially in the field of photography regarding regional imagery. 
b. Overall Presentation Results of Activities

Presentation of changes from each participant after attending the training, namely by presenting changes in the participants represented by their respective group leaders regarding the understanding of the importance of self-image and the image of the region, in this result participants presented the overall results of the training that had been followed namely posting outputs they are on their respective Instagram, participants are required to express what they do with posts their and what they expect from these posts.

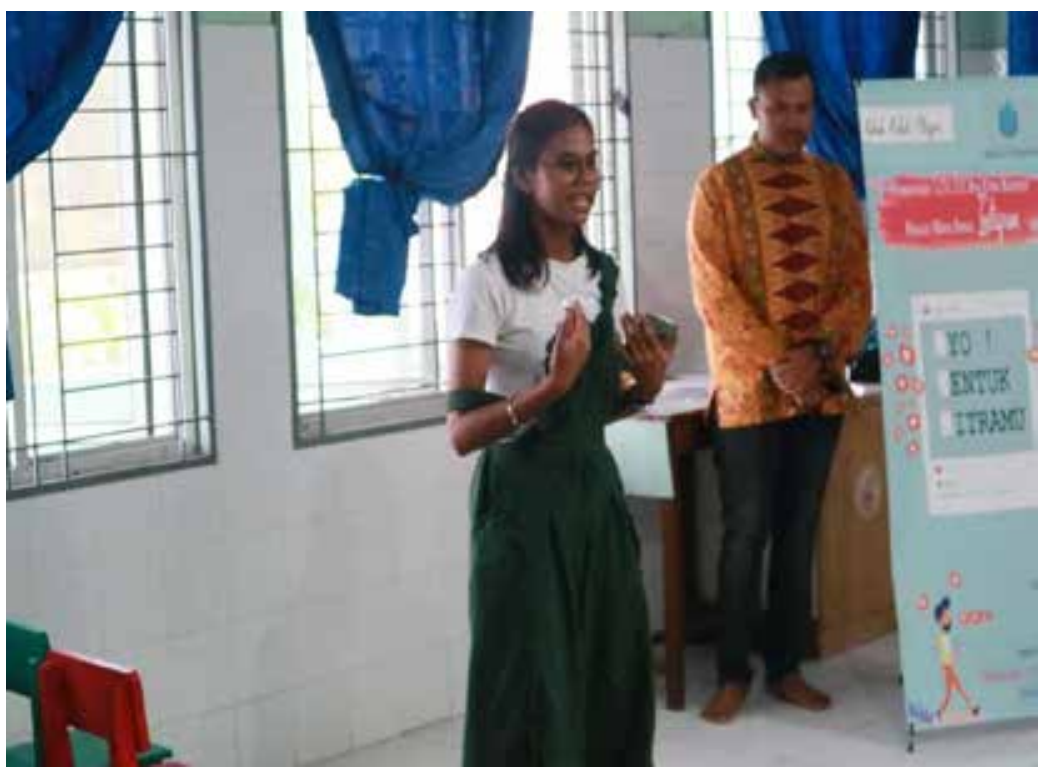

Figure 4. Participants' enthusiasm in PPM activities in describing the perceived changes regarding the understanding of the importance of self-image and the image of the area, which was held at Rumah Kerang, Kalibaru, Cilincing.

Kalibaru area, Cilincing is an area in DKI Jakarta that is still said to be a disadvantaged area, seen from the economic condition of local residents and environmental facilities and infrastructure that have not been supported to be said to be livable areas, Citra Kalibaru Area, Cilincing which was in DKI Jakarta residents at first time I heard the word Cilincing is a slum, arid and remote area compared to the image of DKI Jakarta which has been known as a metropolitan city which is the center of Indonesian government activities, with advancing technology and information that is getting faster and easier for everyone to get information about anything at the moment. in this case it is necessary to touch the development of self-image and regional image to make kalibaru image into an area that also has potential. In this case the self-image is a picture of a person towards himself, related to how a person sees himself and how to think about other people's judgments about him and similarly to the regional image which also becomes an impression or perception between the observer and his environment.

Communities around Kalibaru do not yet know how to increase this potential to build the self-image of the Kalibaru region through social media, social media is an effective channel to provide information and build image to a large audience. The role of teenagers around is very important to shape the regional image and selfimage of adolescents in the environment around the Kalibaru area.

In accordance with Law Number 12 of 2012 on Higher Education article 45 on community service we have done continuously over time, and reach different areas with the aim of reaching the widest possible area in providing benefits and spreading care as a fellow the nation's children and citizens of the Republic of Indonesia. In every area visited in carrying out community service, observations or mini surveys are always carried out, in this case we try to provide a stimulus for the community to improve their quality of cognition and skills that might be followed and developed for the common welfare.

In this community service activity we provide knowledge about communication science, about efforts to build self-image and the image of the region, from this situation we provide socialization to local teenagers about how to use Instagram social media to build their self-image and the image of the Kalibaru area in the surrounding environment. By improving self-image and the region, it can be a positive thing that brings good to both adolescents in the region as well as the Kalibaru itself. Therefore a series of community service programs need to be carried out, among others:

1. First activity, Provision of information about the importance of photographs in improving self-image and the image of the region. This activity is through a presentation on the relationship between photos and self-image or regional image, then tips / strategies for using a camera for photos and editing techniques. 
2. The second activity, ahold review was on the participants, by revisiting the material presented such as photography, techniques editing, self-image and caption. In this activity the speakers focused more on the participants so that they could progress in an effort to improve their self-image and the image of the North Jakarta Kalibaru region. The monitoring process is also carried out at this stage, which is monitoring through whatsapp groups of each group. This monitoring is carried out to remind participants of the contribution in the activity.

3. The third activity, explained the changes of each participant, namely by giving time to the participants to present changes in the participants represented by their respective group leaders on understanding the importance of self-image and the image of the region. In this activity also carried out entertainment activities for the participants namely by presenting the Mercu Buana University Student Choir who sang 2 folk songs in the hope that participants get additional knowledge about Indonesian cultural songs.

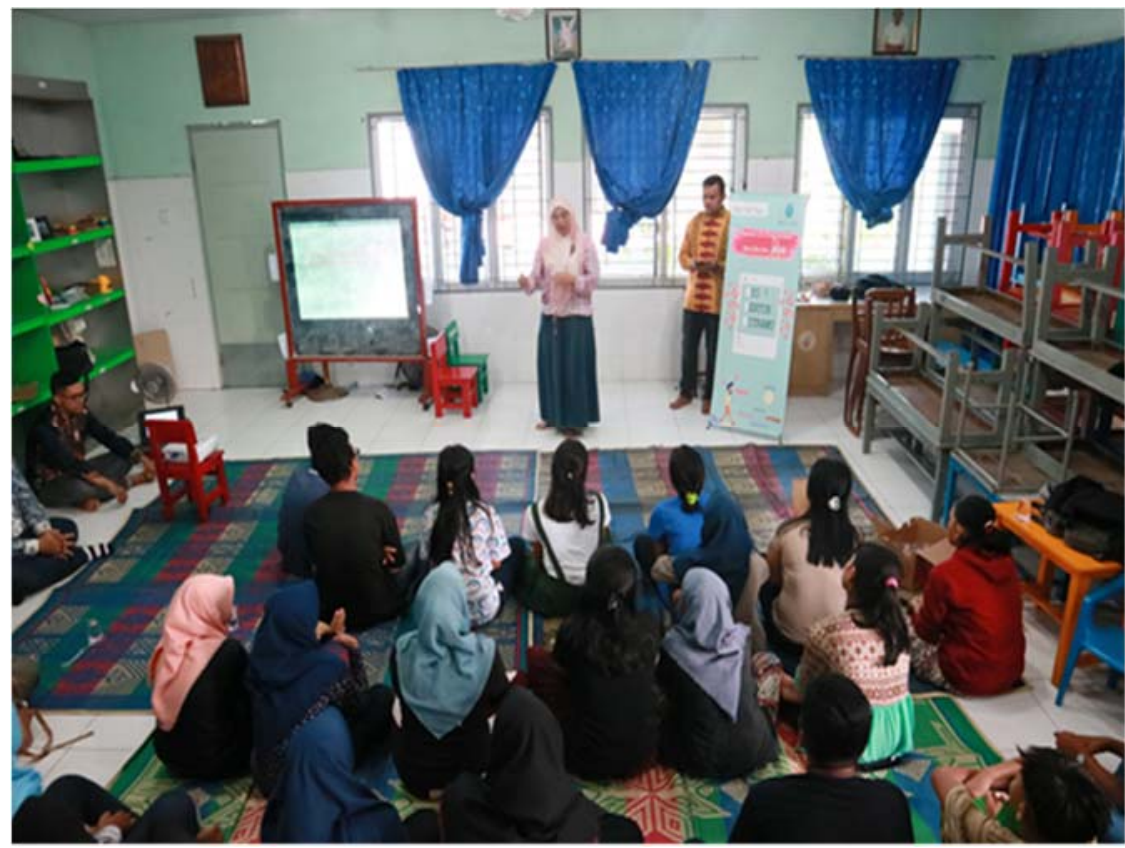

Figure 1. Opening of activities by Dr. Elly Yuliawati at Rumah Kerang, Kalibaru, Cilincing.

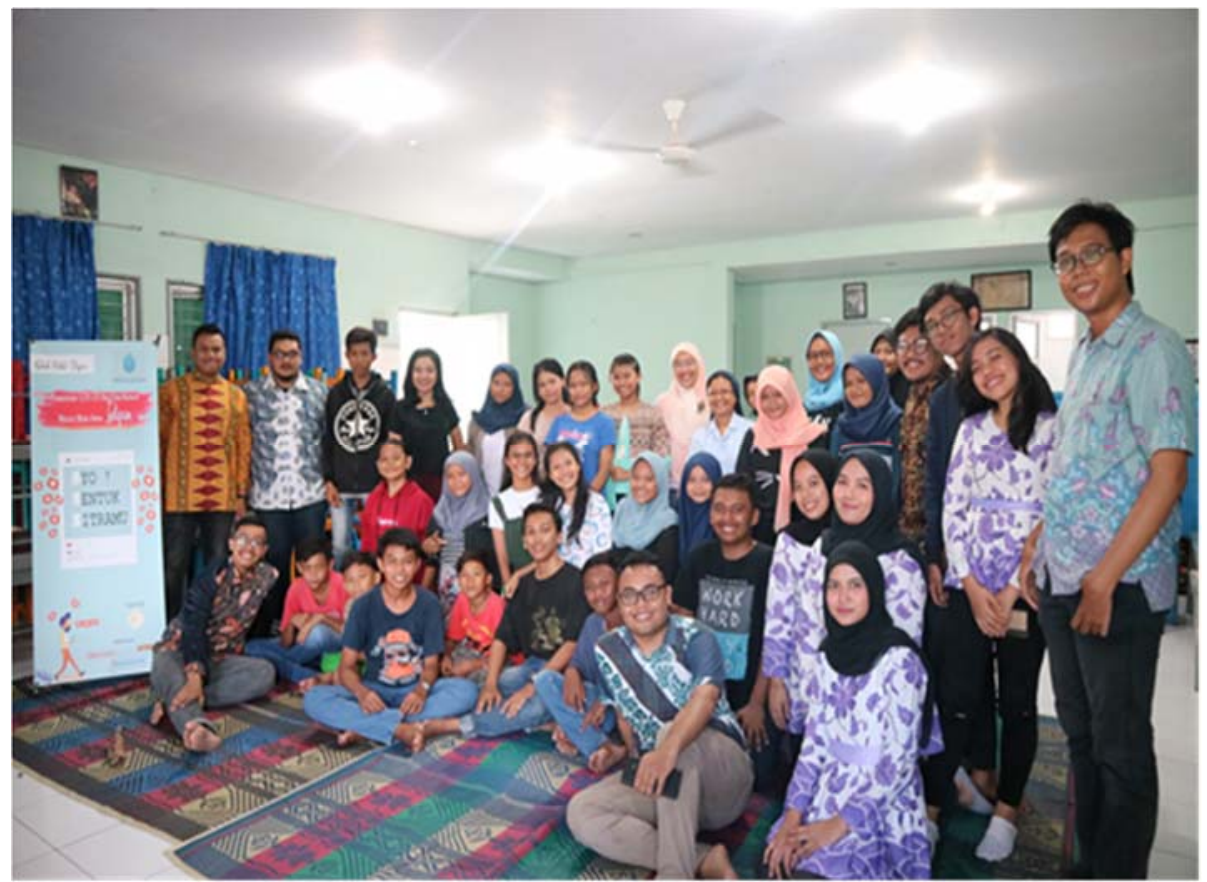

Figure 2. Photo with the organizing team and participants, held at the Kerang house, Kalibaru Cilincing. 
From the results of this activity participants can understand the importance of self-image and the image of the region that needs to be built to open up the broad view of the people of Indonesia about the image of Kalibaru in Jakarta as a decent and potential place, participants also know about the use of Instagram social media in supporting efforts to improve self-image and the region, with the knowledge provided related to how content management in social media gives participants the opportunity to implement it directly. Therefore, along with the development of science, Mercu Buana University actively participates in educating the community through the development of the field of communication science.

\section{CONCLUSION}

Community service activities, resulted in several conclusions, as follows:

1. By holding this activity, adolescents who are in the Kalibaru area get new knowledge about using Instagram so they can improve their self-image and the region.

2. Adolescents in the Kalibaru region have the same potential as young people who are in other regions as the next generation of the nation because of a high level of curiosity about things they do not know yet.

3. With the material on caption, teenagers in the Kalibaru area already have the ability to write as their capital for the future if they want to explore or have an interest in writing.

4. Kalibaru teenagers get the knowledge they need, namely efforts to improve their self-image and the image of the Kalibaru region through social media, especially in the realm of photography.

\section{REFERENCES}

Moede, Nogarsyah, 1993, How to Maintain Environmental Sustainability According to Islam, Bandung, Marjan. Wood, Julia. 2013. Communication Theory and Practice. Jakarta. Salemba Humanika.

Salim, Emi. 1982. Environment and Development. Jakarta. Pearl.

Danusaputro, Munadjat. Environmental Law Book I: General. Bandung. Binacipta. Effendy, Onong Uchjana.1992. Communication Science: Theory and Practice. Bandung. Teen Rosdakarya 